Impact of the non-face-to-face methodology, as a consequence of the COVID-19 pandemic, in the teaching mediation process of higher private education in Costa Rica

\author{
Ph.D. Erika Barrantes Zúñiga \\ erika.barrantes@uh.ac.cr \\ Facultad de Educación \\ Universidad Hispanoamericana \\ MSc. Julio César Castro Miranda \\ julio.castro@uh.ac.cr \\ Facultad de Educación \\ Universidad Hispanoamericana
}

\begin{abstract}
This article shows the results obtained from the research project during the period from June 14 to August 10, 2020, which aims to show the findings of the methodology of the teaching mediation in digital platforms, as a result of the national health emergency, and worldwide, experienced as a result of the pandemic of COVID-19 embodied in the emergency executive decree 42227-MP-S, and based on the official letter issued by the National Authorities, all this in the Republic of Costa Rica.
\end{abstract}

Keywords: research project; teaching mediation; digital platforms. 


\section{Impacto de la metodología no presencial, como consecuencia de la pandemia COVID-19, en el proceso de mediación docente de la educación superior privada en Costa Rica}

\section{RESUMEN}

El presente artículo muestra los resultados obtenidos de un proyecto investigativo realizado durante el periodo del 14 de junio al 10 de agosto del 2020 en el contexto de la educación superior privada, en la que se pretende mostrar los hallazgos de la metodología de mediación docente en plataformas digitales, esto como consecuencia de la emergencia sanitaria nacional, y del urbi, vivida a raíz de la pandemia del COVID-19 plasmada en el decreto ejecutivo de emergencia 42227-MP-S, y con base en el documento oficial emitido por las autoridades oficiales, todo esto en la Republica de Costa Rica.

Palabras clave: proyecto investigativo; mediación docente; plataformas digitales.

Artículo recibido: 10. Junio. 2021 Aceptado para publicación: 16. Julio. 2021 Correspondencia: erika.barrantes@uh.ac.cr Conflictos de Interés: Ninguna que declarar 


\section{INTRODUCTION}

Since March 16, 2020, all the higher educational centers in Costa Rica have been obliged to migrate the face-to-face classes of most of its academic offerings to an alternative methodology such as distance learning through technological platforms. The basis of the decision lies in the emergency not only worldwide, but also nationally, in relation to the SARS-COV2 virus pandemic.

As a result of the emergency declaration issued by the Presidency of the Republic of Costa Rica, in which the decree 42227-MP-S obliged the entire public and private state apparatus whose purpose is the production of goods and services, to make the necessary adjustments so that their activity would not be stopped.

Higher education institutions were requested to make their respective premises to turn their operation to the non-presential nature in the dictation of lessons. An official document was issued that enabled the universities to make the pertinent adjustments, so that the entire academic offer could be carried out through virtualization and nonpresence at the time of receiving and dictating lessons.

As it is stated above, the official document provided the universities with the pertinent guidelines so that its students could continue to receive their respective lessons in the different campuses nationwide.

The maximization of quality and continuous improvement are foundations of high value and importance for the universities, in their slogans of impacting their students in the short, medium, and long term, helping the educational processes to be significant in the hands of professors of high professional practice.

\section{BACKGROUND OF HIGHER EDUCATION IN COSTA RICA}

The different systems of higher education in Costa Rica, have had to overcome major events of the past, such as the rapid exponential growth in student enrollment, as well as the great economic crises of the eighties and early nineties. It was these events that prompted the different governments of Latin American nations to create measures aimed at generating study opportunities for their citizens, through the creation of private universities, whose supreme purpose is to provide these opportunities for academic preparation with the aim of providing their students with cutting-edge tools to face the demanding labor markets that exist today.

In the 1970s, higher education underwent an accelerated expansion due to the rapid 
population growth of the 1950s in Costa Rica. As it can be seen in Table \#1, the exponential growth of enrollment marked the planning route in the creation of study opportunities for the citizenry, as shown in the following table:

Chart \#1: University enrollment in Costa Rica, 1985-2004

\begin{tabular}{|l|c|c|c|c|}
\hline \multirow{2}{*}{$\begin{array}{c}\text { Type of universities and total number of } \\
\text { students }\end{array}$} & $\mathbf{1 9 8 5}$ & $\mathbf{1 9 9 0}$ & $\mathbf{2 0 0 0}$ & $\mathbf{2 0 0 4}$ \\
\cline { 2 - 5 } & $\mathbf{5 8 3 9 3}$ & $\mathbf{6 7 1 3 2}$ & $\mathbf{1 3 3 7 5 5}$ & $\mathbf{1 6 2 9 2 5}$ \\
\hline Public & 50033 & 54999 & 61654 & 75974 \\
\hline Private & 8360 & 12133 & 72101 & 86951 \\
\hline
\end{tabular}

Source: Own elaboration based upon Fernández \& Fernández (2007)

In the period shown above, it is evident that public and private universities in Costa Rica attended a large number of students whose desires to prepare themselves for the work environment, and who were encouraged on a large scale to take higher education studies according to the opportunities and interest to become professionals. The abovementioned growth gives the idea that Costa Rica has diversified its offer of higher education institutions compared to the fifties, in which there was only one public higher education institution, and that in the nineties, it was greatly increased with the appearance of private universities, providing a range of opportunities for students to choose their higher education institution considering socioeconomic and geographic conditions.

As it is shown in the following table, private universities have had an accelerated and exponential growth since the 1980s, compared to public universities, whose growth stagnated in relation to private universities. One of the main reasons why these educational institutions have grown so much is that students are looking for a quick insertion in higher education. One of the main reasons of the students when making the decision to enter a private university lies in the speed of entry, the little bureaucracy to become a university student, and to enhance their job opportunities more quickly by being able to obtain the degree that certifies them as a professional in the educational branch they choose to be part of.

Chart \#2: Evolution of Universities in Costa Rica, 1985-2004

\begin{tabular}{|l|c|c|c|c|c|}
\hline Evolution of universities in Costa Rica & $\mathbf{1 9 8 5}$ & $\mathbf{1 9 9 0}$ & $\mathbf{1 9 9 5}$ & $\mathbf{2 0 0 0}$ & $\mathbf{2 0 0 3}$ \\
\hline Public & 4 & 4 & 4 & 4 & 4 \\
\hline Private & 2 & 8 & 24 & 49 & 50 \\
\hline
\end{tabular}

Source: Own elaboration based upon Fernández \& Fernández (2007) 
Fernández and Fernández (2007) refer to the antiquity of higher education in Costa Rica, stating that:

The history of higher education in Costa Rica is relatively recent, approximately 65 years old. The University of Costa Rica (UCR), created in 1940, assumed sole responsibility for university education until the appearance in the 1970s of three public universities that would meet the need for places to respond to the growth in demand. (p. 7)

Fernández and Fernández (2007) clearly highlight the three stages in which higher education in Costa Rica had its boom and its foundation up to what it is today, indicating that between the seventies and eighties, Costa Rica's public universities were catapulted. On the other hand, the economic crisis of the eighties and nineties that had submerged the Costa Rican nation in a disadvantage of educational and social growth, compared to other nations of the Central American isthmus; propitiated the interest of the leaders and founders of private universities, to undertake in a niche market little explored and exploited, which allowed the growth of private universities, whose vision was materialized with the Official Authorities to provide the citizens with excellent institutions of higher private education.

Since the creation of such visionary institutions, the universities have raised the flag of quality to catapult the academic integrity in the formation of their students, with the clear slogan of providing them with competitive, differentiating, and comprehensive tools in relation to other institutions nationwide. As stated above, some private universities become active members of an institution of higher education accreditation, whose purpose is to accredit careers to provide them with a seal of quality that certifies that the careers meet international standards. Under this seal, many universities have an important high percent of their careers accredited, which provide a guarantee to students that the training they receive in their academic classrooms is avant-garde and of the highest quality in order to obtain integral skills when obtaining a job derived from the career studied.

\section{CHALLENGES AND ADJUSTMENTS OF DURING-PANDEMIC IN THE} TRAINING OF FUTURE PROFESSIONALS AT PRIVATE UNIVERSITIES

The global pandemic caused by COVID-19 has severely impacted all areas of human 
endeavor. Particularly in the field of education, as cited by CEPAL (2020), "[...] this emergency has led to the massive closure of face-to-face activities of educational institutions in more than 190 countries in order to prevent the spread of the virus and mitigate its impact. This quote frames the hard decisions that the universities authorities had to take from the moment the sanitary alert was issued in Costa Rica by the government of the Republic.

In the field of education, Costa Rica has had to make major paradigm shifts, making methodological adjustments in teaching mediation, incorporating technology as an ally to reach all students, changing university classrooms, and establishing the most unimaginable places as classrooms to receive the training offered by universities and their professors. CEPAL (2020) stares that:

A large part of the measures that countries in the region have adopted in the face of the crisis are related to the suspension of face-to-face classes at all levels, which has given rise to three main fields of action: the deployment of distance learning modalities, through the use of a diversity of formats and platforms (with or without the use of technology); the support and mobilization of educational personnel and communities; and attention to the health and integral wellbeing of students. (p.1)

Based on what is mentioned by CEPAL (2020), the universities adjust its academic and administrative operation based on the governing body of private universities in Costa Rica. The aforementioned institution issued an official document, which details all the adjustments that must be considered to turn the academic operation towards alternative means of face-to-face classes.

The enormous challenge and the pragmatic adjustments had to be made abruptly, changing the face-to-face classrooms to the migration to the platforms authorized by the universities authorities: Microsoft Teams and Moodle. Both platforms strengthened the continuity of the academic operation, where the synchrony and asynchrony of classes could be carried out on these platforms. The use of the Microsoft platform brought a great number of advantages that González (2020) highlights:

Microsoft Teams is a tool that is designed for collaboration and working together. It allows students and teachers to have virtual 
meetings, up-to-the-minute conversations, chats, file sharing, virtual whiteboards, and it also allows online document co-authoring and can be easily and simply integrated with hundreds of applications.

Furthermore, Gonzalez (2020) also adds that "[...] Moodle, an educational content management platform, which together with Teams, provided the opportunity to create a perfect simulation of face-to-face classes, but from their electronic devices. The tripartite relationship between the document issued by the governmental institution and the one mentioned by González (2020) provided the universities with the necessary tools to provide continuity of the academic operation, no matter how aggressive the Coronavirus virus was. This structural adjustment was carried out by all the different administrative departments, whose efforts provided the professors with the necessary tools to be able to give lessons even in unfamiliar environments for both students and professors.

With the invention of the Internet, the educational paradigm has opened up to new forms of knowledge that transcend geographical boundaries, in order to reach more people no matter where they are. In the knowledge society, virtual education has acquired a leading role due to its high flexibility of coverage within student populations. In the educational aspect, the Internet has brought with countless benefits by implementing constructivist and collaborative strategies and the potentiation of soft skills such as research, autonomy, among others, through qualitative activities such as virtual forums, e-mails, chats, among others.

These activities highlight the role of teachers as transformers, since they are professionals who are more immersed in the learning process of students and, therefore, more assertive, and cooperative professionals in relation to students and their commitment to acquire relevant knowledge for their professional development. FTP $(\mathrm{n} / \mathrm{d})$ mentions that:

The objective of learning in educational environments is for students to acquire and develop knowledge, skills, abilities, and aptitudes that they must use daily as an exercise in educational centers. Consequently, learning environments are generated by applying new educational technologies that contribute to the access and process of teaching in various disciplines, approaches and practices, with the 
purpose of stimulating meaningful learning in students. (p.10)

Based on what is mentioned by FTP (n/d), learning in education has the purpose of generating favorable environments for students and their acquisition of knowledge, abilities, skills, among others, so that they can be transferred to the real world at the right time when they are working as workers. In addition to the above, educational institutions must be clear and take steps to ensure that these learning environments are the timely response to fortuitous situations such as the pandemic, and are based on the following diagram:

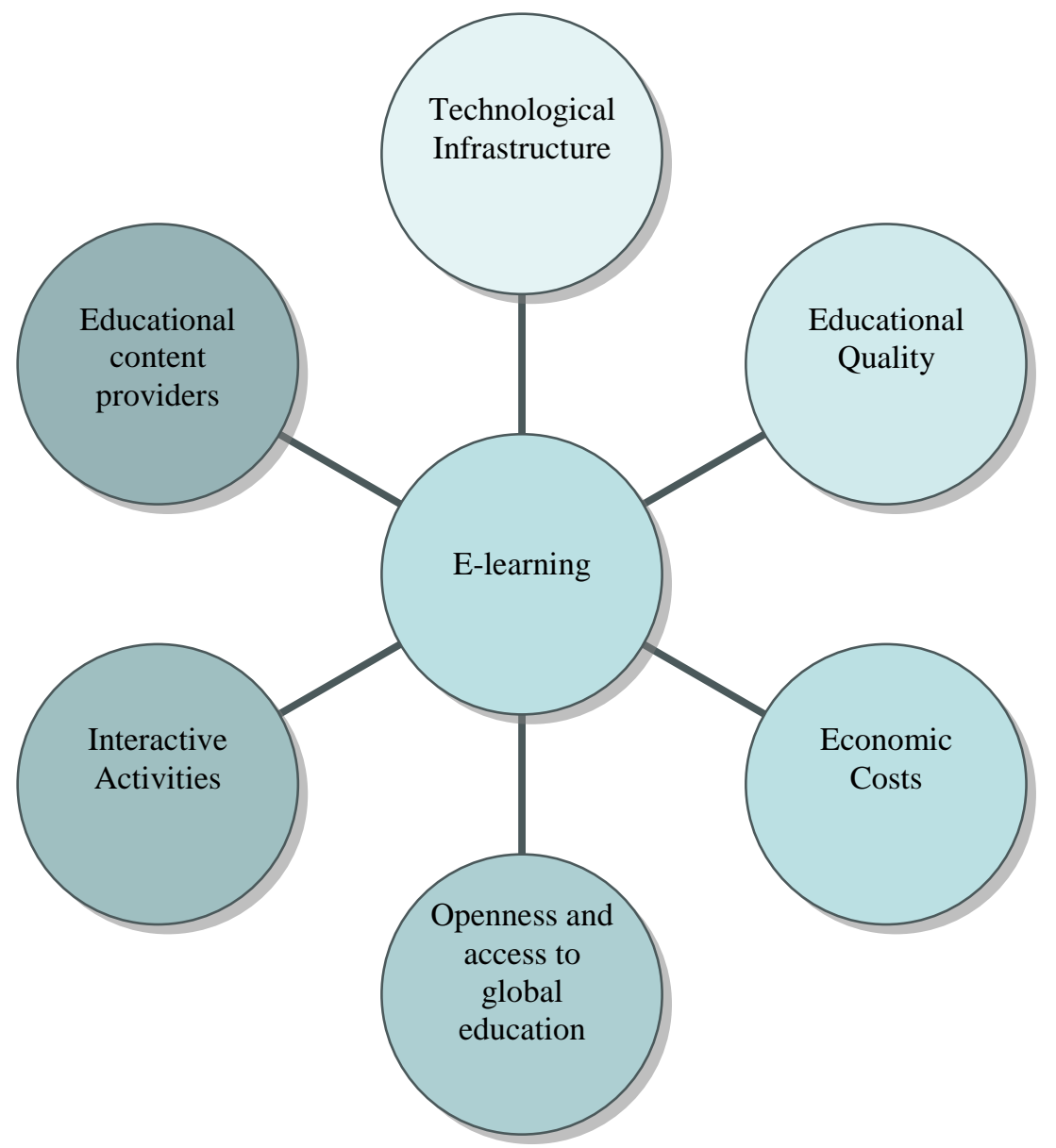

Source: Own elaboration based on FTP $(n / d)$, p.11

Based on the above diagram, the E-learning implemented at the universities has generated a positive impact on the knowledge society of the students of the different careers that are taught in the different faculties, developing a historical milestone in different careers in the Faculties of Education. It is in virtual education that the universities saw a great opportunity to continue teaching lessons even when facing with 
such a complex situation as the Coronavirus pandemic. This methodology responds to the needs of the environment and empowers the universities to continue reaching every student corner where there is a student studying.

In line with this virtual experience, a large part of the higher education institutions and their constant self-evaluation, carried out different consultations with the student body during 2020, with the aim of evaluating the perception of the student population and the classes received during this year, in order to seek continuous improvement, to provide the continuity of the educational process with its high quality standards and to be able to culminate the on-site processes that had begun before the pandemic, always with the intention of making the corresponding contributions in terms of providing follow-up to the educational and curricular policies that clearly aim to develop the skills that the population demands with the slogan that the centers of study become transforming axes of quality in the country.

All the ideas that can be brought together will always be valuable as long as the objective is to allow academic progress in the training of students and future professionals, all those who are involved and committed to education and in this case with Costa Rican education have seen the need to create spaces for discussion, forums that have allowed to know international experiences, so that by articulating ideas can be built and under the guidance of the different experiences to realize a line that allows according to the different contexts to move forward, In addition to leaving in this experience an example for future generations where they can analyze that under a situation as difficult as the one lived by this pandemic, it was achieved in a positive and collaborative way, with an immediate response action the continuity of the processes, clearly many adjustments must be made in terms of teacher training to meet the distance contact of students and make profound revisions in the changes that must be generated at the level of evaluation and that possibly this will be one of the great challenges to make the forms of academic evaluation more flexible both nationally and in the macro evaluation for the revision of international standards that are undoubtedly necessary.

It is important to recognize each one of the mediation processes where academic life must be carried out for the construction of knowledge, to grow and guide the process that will allow us to get out of this crisis and global emergency in relation to education. Possibly many are trying to cope with other issues of public interest such as health and 
the economy of the countries, but it is up to the academy to bring forward this reality that requires all the attention and effort of the different disciplines to drive the educational transformation that is far beyond a curricular transformation, It has to do with a transformation in many directions, including the awareness of government authorities to focus their action on the changes needed in the structure of educational attention, immediate connectivity in all populations but undoubtedly with greater attention to remote and underprivileged populations so that all students have access to combined distance attention. No es posible tener que detener procesos por la incapacidad de accionar interdisciplinariamente, la investigación nos debe mover a reflejar con números las necesidades de cada contexto para tomar decisiones justas para cada población y no generalizar de manera subjetiva sin sustento indagatorio de la realidad de cada comunidad donde se desarrolle la educación.

Based on what is mentioned by Chen (2006) cited by Sampieri et al. (2018), a mixed research approach is proposed to obtain the above mentioned in relation to the reality of each community by mentioning that:

(...) the systematic integration of quantitative and qualitative methods in a single study in order to obtain a more complete "picture" of the phenomenon, and points out that they can be combined in such a way that the quantitative and qualitative approaches retain their original structures and procedures ("pure form of mixed methods"); or that these methods can be adapted, altered or synthesized to carry out the research and deal with the costs of the study ("modified form of mixed methods") (p.534).

This statement by Chen (2006) quoted by Sampieri et al. (2018) allows to collect the feelings of the general population when making an objective x-ray of the reality lived by each community or context.

It is necessary to create spaces for discussion so that the authorities, under the criteria of experts, can have a light to guide the actions to be considered in the following months in order to meet the needs of the world population that demands international connectivity to interact with multiple cultures and scenarios.

\section{FINAL CONSIDERATIONS}

Therefore, once this analysis has been carried out, it is concluded that virtuality does not replace face-to-face attendance one hundred percent, especially in higher education 
generations, where anthropology plays a preponderant role in human relations and contact. In addition, between the study period of 2020, the positive perception of the non-face-to-face methodology by the student body increases considerably as a consequence of one of the actions that the population has been waiting for a long time, the higher education institutions activated their resources and have put them at the service of the population to provide many students with their first distance experience with methodological adaptations that did not cut the healthy progress of the teachinglearning processes that the student body received before the pandemic.

In addition, it is pertinent to give continuity to this methodology adopted by the University communities in the face of the health emergency situation during the time that the pandemic lasts, and in the face of a similar potential situation that makes the continuity of face-to-face attendance impossible. The volatile and convulsive knowledge society and the fourth industrial revolution are based on the awakening of an action and implementation of flexible methodologies, focused on the student, without neglecting the educational quality dictated by the regulatory bodies, to make the student body integrally formed and trained to meet the demands of globalization.

\section{REFERENCES}

CEPAL (2020). La educación en tiempos de la pandemia de COVID-19. https://repositorio.cepal.org/bitstream/handle/11362/45904/1/S2000510_es.pdf

Echeverría Samanes, B. y Martínez Clares, P. (2018). Revolución 4.0, Competencias, Educación y

Orientación. http://www.scielo.org.pe/scielo.php?script=sci_arttext\&pid=S2223$\underline{25162018000200002}$

Estefan Ligarretto, R. (2020). Educación virtual: realidad o ficción en tiempos de pandemia. https://www.javeriana.edu.co/pesquisa/educacion-virtual-realidad-oficcion-en-tiempos-de-pandemia/

Fernández-López, S. \& Alfaro, S. (2007). Evolución de la Educación Superior Costarricense: un análisis de su modelo de financiación. Https://www.researchgate.net/publication/28173346_Evolucion_de_la_Educaci on_Superior_Costarricense_un_analisis_de_su_modelo_de_financiacion

FTP (n/d). La educación virtual en el siglo XXI. http://ftp.campusvirtual.utn.ac.cr/elearning/La\%20educaci\%C3\%B3n\%20virtual\%20en\%20el\%20siglo\%20XXI.pd 
$\underline{\mathrm{f}}$

Gallo, N. (2020). Estudiantes en tiempos de pandemia. https://www.evelia.unrc.edu.ar/ensenaryAprenderEnLaVirtualidad/estudiantesen-tiempos-de-pandemia/

González, A. (2020). Microsoft Teams permite a más de 30 mil universitarios continuar sus planes de estudios en Costa Rica. https://revistaitnow.com/microsoft-teamspermite-a-mas-de-30-mil-universitarios-continuar-sus-planes-de-estudios-encosta-rica/

Hernández, R.; Fernández, E. y Baptista, P. (2014). Metodología de la Investigación. 6a . ed. Editorial McGrawHill: México, D.F.

Mendoza García, C. (2018). Educación superior en la cuarta revolución industrial. https://observatorio.tec.mx/edu-bits-blog/educacion-superior-en-la-cuarta$\underline{\text { revolucion-industrial }}$

Reyes, O. (2021). Educación para la cuarta revolución industrial. https://www.martesfinanciero.com/voz-calificada/educacion-para-la-cuartarevolucion-industrial/

Sanchez Acosta, L. (2020). La virtualidad en tiempos de pandemia: Reto u oportunidad. https://uach.mx/noticias/2020/6/22/la-virtualidad-en-tiempos-de-pandemia-retou-oportunidad/

SINAES (2019). Preguntas Frecuentes. https://www.sinaes.ac.cr/index.php/preguntasfrecuentes 